\title{
The relation between public services and the demand for sustainable city tourism
}

\author{
P. Amrusch \\ University of Vienna, Austria
}

\begin{abstract}
This paper investigates the impact of cultural goods on the housing market considering environmental factors related to tourism in an Italian city. In the first section, the willingness to pay for cultural goods is estimated by using the hedonic pricing model for the commercial property (tourism). In this regression, the link between environmental factors and the number of tourists is studied, which in turn quantifies the prospects for 'sustainable' or at least environmentally friendly tourism. On the basis of the results further questions are posed, e.g., whether tourism increases social welfare for local residents - also in conjunction with public policy.

Keywords: sustainable tourism, marginal willingness to pay for natural heritage, cultural goods, public services, hedonic model, tourism and social welfare, public policy making, urban transport system.
\end{abstract}

\section{Introduction}

Sustainable tourism is a broad and widely interconnected field capturing, i.e., social, economic, environmental, socio-cultural dimensions, mainly to be addressed locally and at the national level, by the public and private sector (see, e.g., sustainable tourism indicators are published by the WTO [1]).

A recent study published by the National Austrian Tourist Office (Österreich Werbung) claims that $10 \%$ of the tourists are disposed to pay for sustainable tourism at the expense of their quality of live [2].

However, in many circumstances, environmentally friendly behaviour does not necessarily incur additional costs for tourists, in particular, when sustainable tourism is promoted at the local level, e.g., by investments in an efficient transport system. 
As market forces do not account for "sustainability", the determination of the intrinsic, non-preference-related value of public services, as nature and cultural goods, appears to be a difficult task.

Since tourism increases social welfare, policy-makers have to focus on sustaining cultural and natural heritage, e.g., to create tourist satisfaction. Specifically, since tourists implicitly attribute monetary value to environmental services and cultural goods. Vanslembrouck et al. (2005) [3] indicate that landscape features positively influence the demand for tourism and have a positive impact on the price tourists are willing to pay for accommodation.

One main aim of the paper is to show whether tourists are disposed to pay additional sums on public services in the city of Padua in 2005, by the use of the hedonic analysis. Moreover, the behavioural consequences are traced in terms of sustainability.

In addition, it may be also discussed whether tourists with the average length of stay of around 2 days in the city of Padua are willing to pay as much for environmental services as tourists spending about 6-7 days in the surroundings of Padua that are famous for thermal springs and natural heritage [4]. However, as the environmental damage (e.g., due to air pollution) may be worse in the city than in the surroundings, as indicated by the shortening average tourists' stay and the higher mobility by tourists, the paper focuses on city tourism. On the other hand, tourists who choose to stay in the surroundings may have a clearer preference for environmental factors. Moreover, in 2005 in comparison to 2004, the total number of tourists increased in the city of Padua, whereas it declined in the surroundings [10].

Padua is one among the Italian cities that risks higher mortality rates due to particulates emitted by urban transport in 2006 [5]. The enlarging city of Padua is an important economic focus (e.g., due to the exhibition), whereas over one million people load the transport system in Padua [6]. Air pollution is also a major environmental problem in Padua, whereas the car is a predominant mode of transport in Italy.

Air pollution also deteriorates cultural and natural resources, whereas public goods visited by tourists are mainly assumed to be "non-consumptive" (see, e.g. Freeman [7]). However, for environmental reasons, the urban traffic in central streets of Padua is limited by public policy, e.g., in the vicinity of the tourist attraction, the Saint Anthony's Basilica. In future, the closure of the whole historical centre is planned [6]. Tourists considered transport facilities to be of medium quality in Padua [8], as inferred in a recent survey 2005/06 of 1166 people. The only fact tourists complained about was the scarcity of parking [8]. According to researchers in the traffic sector (the Traffic Club Austria (VCÖ)) [9], the scarcity of parking may force the reduction of private car use. Hence, questions may be posed whether environmental public policy harms or positively influences city tourism, and/or whether city tourists are willing to pay additional sums on staying in a clean and green environment, near cultural services along with the (transport) infrastructure offered by the city along with the possibility to do their sightseeing by food. In the context of the Paduan urban transport system in 2005 and on the basis of the overall increasing environmental awareness of 
individuals [15], the paper investigates whether tourists choose their accommodation in the vicinity of monuments (irrespective of the accommodation quality), in green areas or pedestrian areas. On one hand, it is to be addressed whether tourists are willing to pay for green attributes (and support the public policy), on the other hand, the paper explores under the existing infrastructural restrictions, whether tourists' behaviour can be considered to be "sustainable" or at least "environmentally friendly" in 2005, irrespectively of the motivation behind the tourists' preferences. The location-specific choices by tourists inductively inferred from market data reveal the "environmentally friendliness" of tourists in 2005/2006, expressed, e.g., by their marginal willingness to pay for public services (cultural heritage and accessibility or reduced travel time to monuments, green and traffic-reduced areas). Thereby, in conjunction with a survey report [8] of 2005/2006 (conducted by the National Tourist Association, Padua Turismo Provincia Padova in three phases: 12.10.9.11.2005; 25.4. 2005 ("the day of the Marathon"); 12.-13.6. 2006), the existing infrastructural restrictions are considered with special emphasis on the public and private transport system's specifics.

However, the paper does not aim at investigating the psychological aspects of "environmentally friendly" behaviour or how tastes developed (e.g., for pure environmental consciousness, efficiency aspects, health-consciousness, emotions and social responsibility or due the interconnection of many aspects).

It is to be pointed out that this investigation may be of particular interest for the public sector - since the year prior to the construction of a new tram in Padua is considered - as well as for investment decisions in the private sector.

\section{Tourism in Padua in 2005}

In the investigation period 2005 city tourism in Padua experienced an increase by $3.57 \%$, whereas in the Province of Padua - known for its thermal springs - a decrease in the number of tourists was observable.

On the basis of the recent survey [8] of 1166 people, $89.5 \%$ declared themselves to be tourists in the city of Padua, another $2.8 \%$ travelled to Padua for professional reasons, another $3.8 \%$ came to Padua to be treated in hospital, another $2.3 \%$ to be cured in thermal spring, and the remaining $1.5 \%$ declared other reasons. In this context, homogeneity of tourists' preferences is observable. In 2005 a number of 493069 Italian tourists and 339462 foreigners visited Padua (205 364 of them were European) [10]. Thereby, 70\% were individuals and families travelling on their own, whereas the remaining $30 \%$ of the tourist travel with organized groups.

Tourists typically associate the city of Padua with "its" famous Saint Anthony [25]. The Saint Anthony's Basilica is also known for its rich cultural heritage with important frescoes by Giusto de'Menabuoi, reliefs created by artists Lombardo, Sansovino, and Donatello. Survey results show [8] that in 2005/2006 $48 \%$ of the tourists visited the Saint Anthony's Basilica due to their devotion to Saint Anthony; whereas the remaining 52\% visited the Saint Anthony for cultural-religious interest and art. Seeing that all tourists visited the Basilica in 
2006, they presumably also visited the other monuments close to the Saint Anthony's Basilica, the sculpture-adorned, often claimed to be the biggest square of Europe Prato della Valle and the Botanic Garden, the Basilica Santa Giustina, San Leopoldo etc. These facts stress the importance of a "sustainable" and efficient infrastructure and public and private transport system near the Saint Anthony's Basilica (a future asset of promotion by the Padua Turismo Provincia Padova [8, 11]) and the other monuments close to it. Other important sights are geographically spread over the historical centre, as, e.g., the ancient Roman Amphitheatre surrounding the Capella degli Scrovegni with the Giotto frescos, the historical university buildings and the Galileo's Astronomical Observatory. However, also the pedestrian area with the café Pedrocchi [25] of historical value and with further interesting sights (as the "Piazzas", the "Palazzo della Ragione" etc.) is considered in the empirical quantification of public services in the following section.
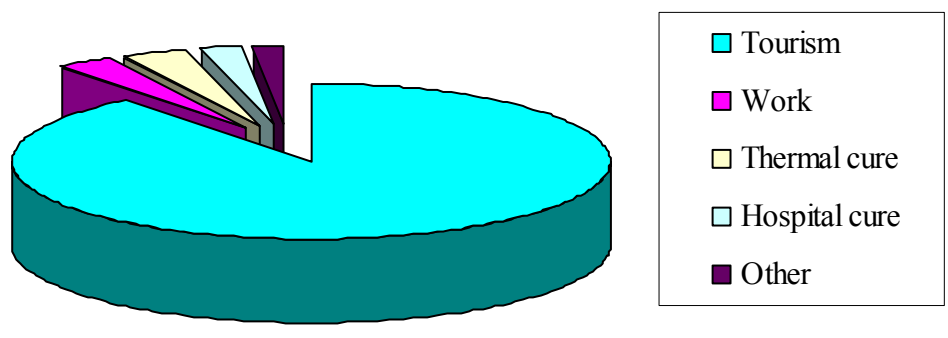

Figure 1: $\quad$ Reasons for travelling to Padua in 2005 [8].

\section{The model and data used}

For the estimation of the monetary value of non-market public services, the hedonic pricing methodology is applied, developed by Rosen [13] and Freeman [12]. Following Turner [14], the hedonic pricing method attempts to infer individual's preferences by looking for a surrogate market of, e.g., complementary goods. The hedonic pricing methodology, as a revealed preference approach, estimates the tourists' perceived changes of a property's environmental characteristic. In Padua, accommodation fees were unchanged in 2005 compared to 2004. Fees (for a double room including a bathroom in the high season) and the corresponding hotel characteristics were obtained from the catalogues annually published by the Padua Turismo Provincia Padova (2005), 
whereby merely hotels and Bed \& Breakfast's are considered in the sample of 70 observations. In 2005 most tourists chose hotels with a 3 and 4 star ranking [10]. As customers might have chosen their hotel or accommodation by the rating, dummy variables (1-4) were created for the stars of a hotel, denoted by "stars". Furthermore, dummy variables were created for Bed \& Breakfasts, denoted by " $B \& B$ ".

An additional variable (denoted by the "vicinity to monuments" is created to consider the geographical distance of the accommodation (correlated with the travel time) to the Saint Anthony's Basilica (visited by all tourists) along with the famous green square Prato della Valle located in the vicinity of the Basilica; taking on the value $=0$ for accommodations outside the city walls and ranges from $0.9-1$ accounting for the geographical distance of accommodations inside the city walls to these 2 monuments. The value is increasing exponentially, as marginally decreasing utility in the distance is assumed. The average travel velocity is assumed to be $4 \mathrm{~km} / \mathrm{h}$; correspondingly, derived by asking tourists directly and not by measurements, as in this approach the perception of "attributes" plays a more crucial role than measurements. Although the considered monuments are located in the near the "geographic" core of the historical centre, in view of the "Ricardo Model", another dummy variable denoted by "central" (ranging from $0-1$ ) was constructed (in a similar manner as the "vicinity to monuments"). Thereby, the central points are considered in a broader context, including all the pedestrian area of the historical centre, the vicinity to the railway station, the public institutions, the central "piazzas" (Piazza della Frutta, etc.) and also the adjacency to other important sights and monuments as the Capella degli Scrovegni (Giotto) and the Galileo's Astronomical Observatory spread over the historical centre. Another locationspecific variable explains the vicinity of hotels and/or Bed \& Breakfast's $(B \& B s)$ to the pedestrian area - denoted by "pedestrian area". It is to be mentioned that in the adjacency to monuments and/or the historical centre, there was less air pollution in 2003 [23], the more varied was the public transport system (e.g., more types of buses (minibuses etc.) available in 2005 [22, 23]) and the more streets were limited for private transport in 2005. Moreover, in the vicinity of the Saint Anthony's Basilica tourists could also make use of a public bike rental system. However, as farther hotels and B\&Bs may be advantageous with respect to the accessibility to highways, a further dummy variable is constructed, taking on the value 1 for the vicinity to a highway, and zero otherwise. Additionally, information on benzenes, particulates and the number of buses in the adjacency to hotels and B\&Bs is collected [23]. Tourists could find all hotels ("1-2 Star Hotels" and "3-4 Star Hotels") and B\&Bs inside and outside the historical city walls.

As noted by Turner [14], air quality is likely to be exhibiting marginal diminishing utility, for which reason the willingness to pay for public services could be expressed by the log-lin functional form. Moreover, according to Chay and Greenstone [26], equilibrium marginal willingness to pays seem likely to be higher for cleaner than for dirtier areas (even if they could be evaluated at a comparable level of emissions) [15]. Prior to choosing the frequently used 
functional log-lin relationship, different functional forms are tested. As neither classical utility nor production theory can specify the functional form of the hedonic pricing function [16], the frequently used functional log-lin relationship is selected - being additionally of statistical superiority over other functional forms. For further literature on empirically testing functional forms see, e.g., Halvorsen and Pollakowski [17], Cassel and Mendelsohn [18], Cropper et al. [19], Heckman et al. [20].

Performing a Chow Test, most coefficients for the Bed \& Breakfast's as well as for the 1-2 star hotels and the 3-4 star hotels are significantly different. Hence, additional dummy variables have been created for the Bed \& Breakfast's (B\&Bs), the dummy variables "1-2 Star Hotels" and "3-4 Star Hotels" to be multiplied by the selected explanatory variables.

The following table 2 presents the final regression results including only highly significant variables with the absolute $t$-statistics in parenthesis. The explanatory power is satisfactory, explaining around $70 \%$ in the variance in $\ln$ (accommodation fee).

Table 1: $\quad$ Hedonic model.

\begin{tabular}{|c|c|}
\hline Constant and variables & Coefficients \\
\hline Constant & $\begin{array}{r}4.104079 \\
(71.1)\end{array}$ \\
\hline Vicinity to monuments*3-4-Star & .211445 \\
\hline Hotel & $(2.6)$ \\
\hline Vicinity to monuments* $\mathrm{B} \& \mathrm{~B}$ & $\begin{array}{l}.463 \\
(4.0)\end{array}$ \\
\hline Stars*(1-2 Star Hotel+3-4-Star Hotel) & $\begin{array}{r}.251190 \\
(10.2)\end{array}$ \\
\hline Garden*(3-4 Star Hotel+B\&B) & $\begin{array}{c}.151902 \\
(2.1)\end{array}$ \\
\hline Number of buses*B\&B & $\begin{array}{c}-.000299 \\
(5.1)\end{array}$ \\
\hline $\begin{array}{l}\mathrm{R}^{2}=0.70, \text { Adj. } \mathrm{R}^{2}=0.67, \mathrm{JB}=4.17 \\
\text { Dependent variable: } \ln (\text { accommodati }\end{array}$ & $\begin{array}{l}\text { ber of observations }=70 \text {. } \\
\text { in } €) \text {. }\end{array}$ \\
\hline
\end{tabular}

Microeconomic theory concerns actual choices and their consequences, whereas rational individuals rank available alternatives and choose what they most prefer.

As expected, customers chose their hotel by it's rating, whereby for an upgrade by about one star in the hotel ranking, tourists were disposed to pay around $25 \%$ more of the accommodation fee.

The variable "vicinity to monuments" was found to be more significant than the variable central. However, the variable "vicinity to the pedestrian area" was found significant only at a $90 \%$ confidence level, for which reason the 
coefficient does not appear in the regression results. The estimates show that for reduction in travel time to the Basilica S. Anthony and Prato della Valle by one unit (around 9 minutes by food), tourists - searching for accommodation in B\&B and 3 or 4 star hotels - were additionally willing to pay around $46 \%$ and $21 \%$, respectively, of the accommodation fee.

However, since tourists revealed their preferences for accommodating near the monuments, tourists were presumably also willing to pay to reduce their car use (by walking or making use of public transport) to reach, e.g., the Saint Anthony's Basilica, supporting efficient and environmentally friendly sightseeing due to the better provision of public transport facilities (as the improved density of bus routes or the possibility of making use of a rental bicycle system, the limited traffic for private transport), the reduced problems related to scarcity of parking, traffic jams and other inconveniences. In other words, improved accessibility increases customer satisfaction and reduces environmental problems related to urban transport, whereby these results indicate that in favour of improved accessibility tourists were indirectly willing to pay to reduce their car use.

The additional information that tourists attribute monetary value to natural resources reveals the importance of "green" and "clean" areas in city tourism: in spite of the short average length of stay of city tourists, they are disposed to pay about $15 \%$ more for accommodating in B\&Bs or 3-4 star hotels offering the use of a garden. Tourists are disposed to pay more for their B\&Bs by about $29 \%$ in favour of a reduction of daily frequency of bus operating by 1000 in the street the $\mathrm{B} \& \mathrm{~B}$ is located. As the number of buses is positively correlated with air pollution and major roads, this suggests that tourist demand quiet and clean air.

Hence, these results support the importance of the provision of the necessary infrastructure to promote "sustainable tourism" and with it "environmentally friendly" behaviour of tourists as well as to satisfy the demand of tourists for public services.

\section{Final remarks}

These results show that also city tourists in Padua demand a clean and quiet environment, spending additional sums on traffic-reduced and green areas (as, e.g., in the vicinity of monuments). Tourists display a higher willingness to pay for green, as the city tourists' preparedness to pay for the possibility to use a garden demonstrates. At the same time, being willing to spend additional money for staying in the vicinity of monuments (due to accessibility criteria and the better infrastructure), tourists are ready to considerably reduce their private car use. Surprisingly, although tourists demand accessibility, they are also disposed to pay additional sums to stay in hotels and B\&Bs not located near a main bus route (characterized by a higher number of buses operating), where noise and traffic emissions are more intensive. Consequently - irrespective of the motivation behind city tourists' preferences, not only "country-side", but also city tourists have preferences for "sustainable" sightseeing. Typically, as said by 
tourist agencies: "...sustainable behaviour can be attributed to tourists who choose to stay in rural areas and in touch with nature...[24]."

On the basis of the market mechanism, the tourist's demand for a sustainable and efficient infrastructure improves and protects natural and cultural resources, since a positive correlation between tourist attractions (e.g., near the Saint Anthony's Basilica and famous square Prato della Valle), public services (infrastructure, environmental and cultural heritage) and social welfare is observable. Evidently, there is an interconnection between tourism and the social welfare: The increase in the overall price level near tourist attractions is reflected, inter alia, in the prices demanded in restaurants in the vicinity of the Saint Anthony's Basilica, the square Prato della Valle and pedestrian areas (café "Pedrocchi"). For instance, the increase in social welfare near monuments induced by tourism also makes inhabitants willing to pay more for residential housing in the vicinity to monuments in Padua [21]. Moreover, correlation matrixes show that the variables "vicinity to monuments"/"vicinity to pedestrian areas" "number of buses"/"particulate matters"/“benzenes" [23] are slightly negatively correlated, implying that the city tourists' preferences for a clean environment and cultural services may indirectly reduce the emission level. The protection of the natural and cultural heritage as well as sustainability does not only conserve the intrinsic value of nature and human's health positively influencing indirectly social welfare, but also attributes - e.g. through increased city tourism - monetary value to market goods in the private, but also public sector. Moreover, city centre preservation attributes an additional social value to the city. On the other hand, in Padua, crime rates (Via Anelli), air pollution and housing prices are also positively correlated [21].

Consequently, it is plausible to promote a clean environment by city planners - also in order to satisfy the demand of city tourists who demonstrated their willing to pay for accommodating near green areas, traffic-reduced areas and for minimizing the distance travelled to monuments and with it for the reduction of car use.

According to this study, the planned public interventions to close the access of the historical centre to private cars and to activate a tram in 2006/2007 should have a positive impact on sustainable city tourism and the quality of life of local inhabitants, as well as on natural and cultural heritage. A possible future analysis could be a detailed analysis of the correlation between (city) tourism and purchasing power in cities of different size and in states varying in the price level. Besides, the analysis could be amplified to the 'Paduan' country-side tourism.

\section{References}

[1] Indicators of Sustainable Development for Tourism Destinations (2004). World Tourism Organization (WTO), www.world-tourism.org.

[2] Österreich Werbung, Bulletin, Touristik-Magazin für PraktikerInnen, Nachhaltiger Tourismus „Auf die sanfte Tour“ pg. 12., July 2006. www.austria.info/bulletin. 
[3] Vanslembrouck, I., Van Huylenbroeck G., and Van Meesel, J. Impact of Agriculture on Rural Tourism: A Hedonic Pricing Approach. Journal of Agricultural Economics, 56 (1), 2005.

[4] Marchioro, S. Personal communication, 29. Juli 2006, director, Turismo Padova Terme Euganee.

[5] World Health Organization (WHO), Regional Office for Europe, M. (ed.), Martuzzi, M., Mitis, F., Lavarone, I., Serinelli, M., Health impact of PM10 and ozone in 13 Italian cities, 2006. www.euro.who.int/document/e88700.pdf.

[6] Marchioro, S. Personal communication, 24. July 2006, director, Turismo Padova Terme Euganee.

[7] Freeman, M. C., The Measurement of Environmental and Resource Values, Theory and Methods, Resources for the Future: Washington, DC, 2003.

[8] Turismo Padova Terme Euganee e Provincia di Padova. Survey report, Indagine sul Turismo religioso: Il Santo apre le porte della città ai turisti. Indagine sul turismo religioso, 27. June, 2006.

[9] Frey, H., Personal communication, 9 March 2006, Verkehrsclub Österreich (VCÖ). www.vcoe.at.

[10] Turismo Padova Terme Euganee, Ufficio statistica, M. Masiero, C. Gibellato. Provincia di Padova. Flussi turistici Provinciali e per ambito 2005.

[11] Marchioro, S. Personal communication, 21. July and 30. June 2006, director, Turismo Padova Terme Euganee.

[12] Freeman, A.M., III, On Estimating Air Pollution Control Benefits from Land Value Studies. Journal of Environmental Economics and Management 1 (1), 74-83, 1974.

[13] Rosen, S., Hedonic Prices and Implicit Markets: Product Differentiation in Pure Competition, Journal of Political Economy 82, pp. 34-55, 1974.

[14] Turner R. K., Sustainable Environmental Economics and Management: Principles and Practice, London pp. 120, 226, 1993.

[15] Zabel, J.E., Kiel, K.A. Estimating the Demand for Air Quality in Four U.S. Cities. Land Economics 76 (2), 174-194, 2000.

[16] Eatwell J. and others, The Palgrave Dictionary of Economics, The Macmillan Press Ltd., pg.632, 1987.

[17] Halvorsen, R. \& Pollakowski, H.O., Choice of Functional Form for Hedonic Price Equations. Journal of Urban Economics 10 (1), 37-49, 1981.

[18] Cassel, E., Mendelsohn, R. The Choice of Functional Forms for Hedonic Price Equations: Comment. Journal of Urban Economics, 18, 135-142, 1985.

[19] Cropper, M. L., Deck, L.B. \& McConnell, K.E. On the Choice of Functional Form for Hedonic price Functions. Review of Economics and Statistics 70 (4), 668-232, 1988.

[20] Heckman, J., Matzkin, R. \& Nesheim, L., Simulation and Estimation of Hedonic Models. In Kehoe, T.J., Srinivasan, T.N., Whalley, J. (eds.), 
Froniers in Applied General Equilibrium Modeling, In Honor of Herbert Scarf. UK (among others) Cambridge University Press, 2005.

[21] Amrusch, P., The impact of urban traffic and environmental factors on the housing market: An analysis of the Italian and Slovenian urban areas. Proc. of the Int. Conf. on Urban Transport and the Environment, eds. C.R., Brebbia, Wessex Institute of Technology, UK, and L. Wadhwa, James Cook University, Australia, 2005.

[22] Azienda Padova Servizi (APS), www.aps.it.

[23] Agenzia Regionale per la Prevenzione e Protezione Ambientale del Veneto (ARPAV). 2002a. Rapporto annuale sullo stato dell'ambiente a Padova 2002.

[24] Gudmundsson, E., Personal communication, 22. 8. 2006, press agent of the National Tourist Office Austria (Österreich Werbung).

[25] Turismo Padova Terme Euganee, Padova - Città d'Arte, 2003.

[26] Chay, K. Y., Greenstone, M. Does Air Quality Matter? Journal of Political Economy 113 (2), 376-424, 2005. 